\title{
Introducing Electrospinning Technique for Producing Nanofibers to Improve Scientific Literacy of Senior High School Students
}

\author{
Ade Yeti Nuryantini ${ }^{a, 1}$, Abdul Rajak ${ }^{b}$, Muhamad Prama Ekaputra ${ }^{b}$, Annisa Rahma ${ }^{c}$, \\ Muhamad Miftahul Munir $^{\mathrm{b}, 2}$, Khairurrijal $^{\mathrm{b}, 3}$ \\ ${ }^{a}$ Department of Physics Education, Faculty of Education and Teaching, Universitas Islam Negeri Sunan Gunung Djati, \\ J1. A.H. Nasution 105, Bandung, Indonesia \\ ${ }^{\mathrm{b}}$ Department of Physics, Faculty of Mathematics and Natural Sciences, Institut Teknologi Bandung, \\ Jalan Ganesa 10, Bandung 40132, Indonesia \\ ${ }^{c}$ Pharmaceutics Research Division, School of Pharmacy, Institut Teknologi Bandung, \\ Jalan Ganesa 10, Bandung 40132, Indonesia \\ 1 adeyetin@gmail.com, ${ }^{2}$ mmmunir.itb@gmail.com, ${ }^{3}$ krijal@ fi.itb.ac.id
}

\begin{abstract}
One of major goals in science education is to assist students in developing their interests in science. Students' attitudes toward science will determine the success of this goal. One of the students' science attitudes is related to the students' response to the development in science, technology and scientific issues. Understanding science, technology and scientific issues is an effort to prepare students for modern life and empower students to make decisions regarding the impact of the science and technology in their lives. This paper describes the method to improve the scientific literacy of senior high school students by introducing the development of science and technology of nanofiber and how to fabricate them using electrospinning tchnique. Exciting media including animation, video, presentation, and discussion were utilized to explain science and technology of nanofibers in detail and how to produce them using electrospinning technique. Evaluation questionnaires regarding student's interest, attention, response to issues of science and motivation were prepared to assess the students' attitudes towards science. It was found that the introduction of electrospinning technique for obtaining nanofibers could improve student's interest, attention, response to issues of science and motivation towards science.
\end{abstract}

Index Terms- Electrospinning, nanofiber, science attitudes, scientific literacy, senior high school

\section{Introduction}

The development of science and technology has been growing rapidly over the time. This development brings positive and negative impacts. Therefore, the rapid development of science and technology must be accompanied by an individual ability to understand science and technology itself, so that every individual has an alternative solution to the problems posed by the development of science and technology.

Science education is expected to be a vehicle for students at schools to gain more knowledge in science, so that students can learn about themselves, their natural surroundings, as well as prospects for further developments in applications in everyday life [1]. Science education is also expected to result in the generation of science and technology literacy.

Unfortunately, designs of learning science at school barely motivate students to develop interest in learning about science. A previous study found that students' motivation and interest are often turned off at a young age [2]. Current learning designs that are still centered on a teacher, comprehension of materials that is achieved by simply memorizing concepts, students that are not actively involved in learning science, numerous and tedious calculations using and applying formulas only, and lack of the opportunity for students to ask questions are some of the factors that lead to low student motivation to learn science [3].

Poor motivation of students affect their attitudes toward science and motivation to pursue a career in science [4] Students often view science lesson as a lesson that is complicated, tedious, and difficult, so that a lot of students decides to choose a career outside science. Osborne, et al. observed that the decline in interest in science occurs in 16year old students. Such conditions contribute to the lack of understanding of science and technology among general public schools [5].

Moreover, Osborne, et al. stated that the attitude toward science is a modification of a scientific attitude [5]. Delivery of science is related to attitudes in response to the development of science, technology and science issues. On the other hand, the attitude of science is a part of scientific literacy. In addition, in the world of education, science attitude is a part of the affective domain [6,7]. PISA 2006 evaluated student's attitudes in three areas: interest in science, support for scientific enquiry and responsibility towards resources and environments [8].

Considering the importance of students' motivation in learning science, a study was done by introducing nanofibers and how to produce them using electrospinning technique as an example of the development of science and technology. Methods for introducing the electrospinning technique and nanofibers products were described in detail through exciting media including presentation, discussion, animation, and video. The students involved in the study were from SMK Bakti Nusantara 666 vocational senior high school (SMK$\mathrm{BN})$, Bandung, Indonesia. In this paper, we report the study on students' attitudes including of interest, attention, response to the issues of science and technology, and motivation in science.

\section{Methods}

Introduction of nanotechnology activities was conducted on Thursday, July 16, 2014 at the SMK-BN. The number of 
participants who attended this activity was 118 students, consisting of 57 female students and 61 male students. The entire class XII students were majoring in Software Engineering. The students gathered in the hall. Activities took place from 09:00 am until 12:00 am. The introduction was done by describing about nanotechnology interactively assisted with video and animation media. At the end of the activities, discussion and question-and-answer session were carried out. Lastly, the students were given a questionnaire about their attitudes toward science. The questionnaire consisted of 35 statements. In principle, the questionnaire was divided into 4 groups of statements, namely (1) interest, (2) attention, (3) response to issues of science, and (4) motivation toward science. Two different statements regarding these items were expected: positive statements and negative statements. The answer option for each item on the questionnaire has a gradation from very positive to negative, expressed in words: strongly agree, agree, doubt, disagree and strongly disagree to the statement for the positive and negative statements gradation is reversed. For the purposes of quantitative analysis, statements with positive criteria were represented by the following scores: $1=$ strongly disagree, 2 = disagree, $3=$ hesitate, $4=$ agree, and $5=$ strongly agree. For statements with negative criteria, the scores interpreted as follows: $1=$ strongly agree, 2 = agree, 3 $=$ hesitate, $4=$ disagree, and $5=$ strongly disagree.

To answer the descriptive formulation of the problem, calculation was done by dividing the total score of the results of research with the ideal score, and thus obtained in the form of a percentage (\%) by using the formula in Eq. (1).

$$
N P=\frac{R}{S M} \times 100 \%,
$$

where NP is the percent value which is sought or expected, $\mathrm{R}$ is the raw scores obtained, and SM is the ideal maximum score of the test in question.

To compare the means of female and male students, the t-test was used. The t-test assesses whether the means of female and male students are statistically different from each other. The t-test is commonly based on the assumption that data population conforms to a normal distribution and two groups share a common variance. Testing for normality used Kolmogorov-Smirnov test and Levene's test was used to determine the equality of variance. In the case of other data that did not well-represented by a normal distribution, nonparametric statistical test (Mann Whitney U test) was used [9].

\section{Results and Discussion}

The study began with a lecture describing electrospinning technique. The lecture was conducted in an interactive manner, assisted by video and animation. During the lecture on introduction to the electrospinning technique for producing nanofibers, students were fairly enthusiastic. The students seemed to be interested in this activity and they paid full attention, particularly because the lecture was assisted by engaging tools such as video and animation. Some of the students could relate electrospinning technology with other familiar technologies in daily life, which were known from television or reading materials. At the end of lecture and discussion session, a questionnaire was given to the students in order to obtain illustration of their attitude towards science. The questionnaire involved two data as follows:

1. The questionnaire regarding attitudes towards science which was associated with interest, attention, response, and motivation in science.

2. The questionnaire regarding attitudes towards science related to student's gender which was associated with interest, attention, response, and motivation in science.

The degree of attitude towards science as a response after the lecture regarding electrospinning method was determined in a percentage. Overall, positive response to the lecture was obtained, with the degree of attitude towards science of $69.84 \%$. The degrees of four variables studied: interest, attention, response and motivation, were $69.05 \%, 69.22 \%$, $69.89 \%$ and $71.04 \%$, respectively (shown in Figure 1). These mean the lecture on technology conducted in this study resulted in a positive interest, attention, response and motivation of the students to learn science in general.

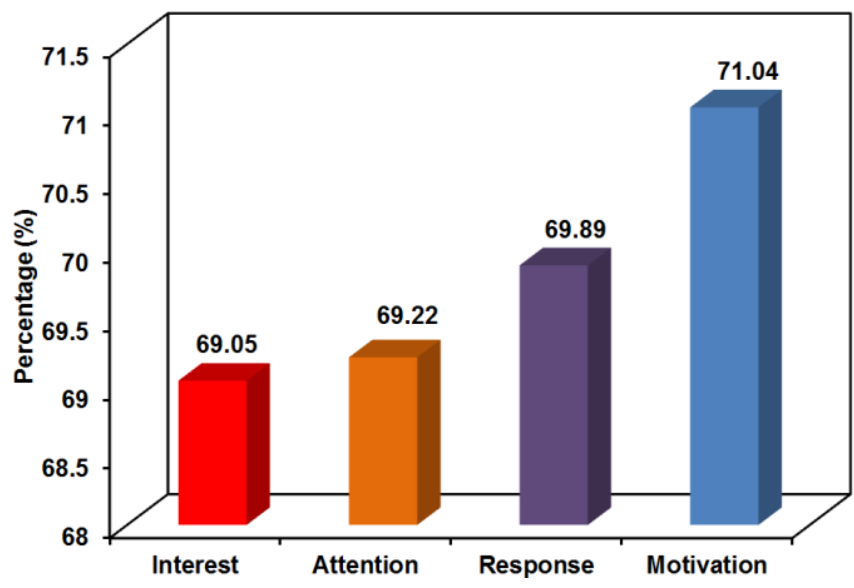

Fig. 1 Percentage of interest, attention, response, and motivation of students toward science.

The number of samples in this study consists of $48 \%$ of female students and $52 \%$ of male students. Average degree of attitude towards science for female students was $71.45 \%$ from expected. This figure was calculated based on four indicators: interest at $71.2 \%$, attention at $70.9 \%$, response at $72.1 \%$, and motivation at $71.6 \%$. On the other hand, average degree of attitude towards science for female students was $68.3 \%$ from expected. Figures for the four indicators, which are interest, attention, response, and motivation, were $67.0 \%$, $67.7 \%, 67.8 \%$, and $70.6 \%$, respectively. The obtained data is shown in Figure 2.

Data regarding students' interest in science was not normally distributed as shown from significance-value (0.000) in Table 1 were less than 0.050. Therefore, nonparametric test (Mann-Whitney U test) was used. Table 2 shows SPSS output for the rank table that provides information regarding the output of the actual MannWhitney $U$ test. It shows mean rank and sum of ranks of the score for interest of two groups: female and male students. The group with the highest mean rank considered as having 
the higher interest. In this case, the females group had the highest interest.

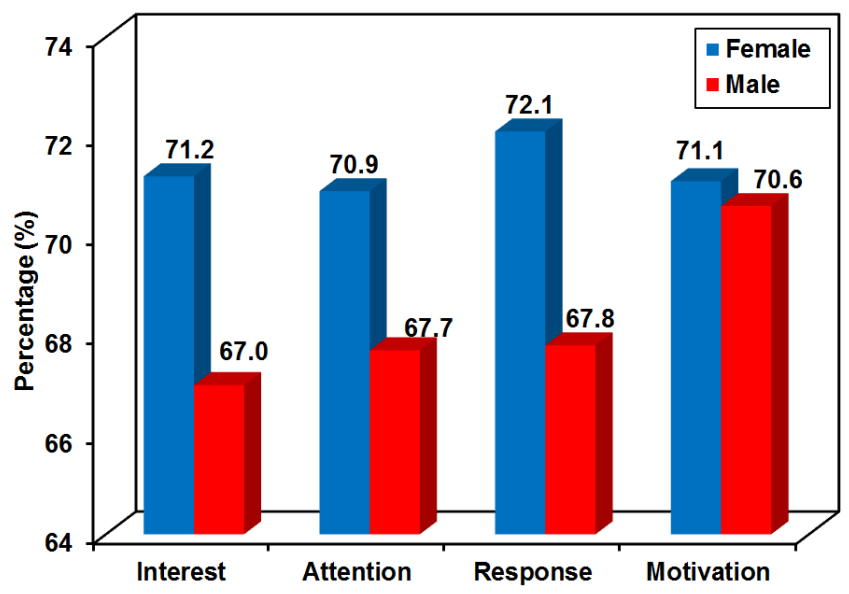

Fig. 2 Percentage of interest, attention, response, and motivation regarding science in female and male students.

Table 1 Siginificance-value of normality test for students' attitude towards science.

\begin{tabular}{|l|l|l|}
\hline \multirow{2}{*}{} & \multicolumn{2}{|l|}{ Kolmogorov-Smirnov } \\
\cline { 2 - 3 } & Df & Sig. \\
\hline Interest & 118 & 0.000 \\
\hline Attention & 118 & 0.084 \\
\hline Response & 118 & 0.092 \\
\hline Motivation & 118 & 0.200 \\
\hline
\end{tabular}

Table 2 Mean rank and sum of ranks of the score for interest of female and male students.

\begin{tabular}{|l|l|l|l|l|}
\hline & Groups & $\mathrm{N}$ & Mean Rank & Sum of Ranks \\
\hline Interest & Male & 61 & 53.19 & 3244.50 \\
\cline { 2 - 5 } & Female & 57 & 66.25 & 3776.50 \\
\cline { 2 - 5 } & Total & 118 & & \\
\hline
\end{tabular}

From the calculation of Mann-Whitney $U$ test as shown at Table 3, the actual significance-value of the statistic test is 0.038 (less than 0.050). It can be concluded that female student's interest was statistically significantly higher than male students.

Table 3 Significance value of the Mann-Whitney U statistic test.

\begin{tabular}{|l|l|}
\hline & Interest \\
\hline Man-Whitney U & 1354.000 \\
\hline Asymp. Sig.(2-tailed) & 0.038 \\
\hline
\end{tabular}

Data regarding attention, response and motivation were normally distributed, as shown from the significance-value in Table 1. The significance values for attention, response and motivation were $0.084,0.092$, and 0.200 , respectively. These values were higher than 0.050 and they are thus considered to be distributed normally. Therefore, parametric test (independent sample t-test) was performed.

The t-test assumes that the variability of each group is approximately equal. The homogeneous data can be obtained from Levene's test with the interpretation as follows: if the resulting significance value of Levene's test is less than the significance level $(\alpha=0.05)$, it is concluded that there is a difference between the variances in the population, while if the significance value is higher than the significance level $(\alpha=0.05)$, it is concluded that there is no difference between the variances in the population. The significance values of Levene's test of attention, response and motivation of female and male as shown in Table 4 were greater than 0.05 and it could be concluded that the variances of attention, response and motivation of female and male were homogeneous.

Table 4 Significance value of the Levene's test.

\begin{tabular}{|l|c|l|}
\hline & F & Sig. \\
\hline Attention & 2.495 & .117 \\
\hline Response & .003 & .955 \\
\hline Motivation & 1.357 & .246 \\
\hline
\end{tabular}

These results indicate that the assumption of homogeneity has been fulfilled and hypothesis testing with ttest was continued. As a reference, the interpretation was set as follows: if the significance value $<0.05$ it means that there is statistically significant difference between the attitudes towards science of female and male students, while if the significance value $>0.05$ it means that there is no statistically significant difference between the attitudes towards science of female and male students.

Based on the significance-value in the first row of Table 5 , the significance value for attention is $0.094(>0.050)$, which means that there is no significant difference in attention between male dan female students. The significance value for response is $0.035(<0.050)$, indicating a significant difference occurs in response between male dan female students and the significance value for motivation is 0.604 (>0.050), indicating no significant difference is observed in motivation between male dan female students.

Based on the results of the questionnaire, the interest, attention, and response of the students at SMK-BN can be classified as fairly good, while motivation can be classified as good. The response of students after the lecture regarding the electrospinning technique was positive. Although students' attitude toward science has decreased at higher ages, students at the age of 8/9 years more enthusiastic in learning science [2]. Moreover, Osborne, et al. observed that declining interest in science occurs in 16-year old students [5]. The decline in students' interest in science could be caused by non-contextual, too theoretical and abstract learning. In addition, students are not encouraged to know the actual environmental conditions.

No significant differences in attention and motivation were observed between female and male students. However, the interest and response for female students were higher than those for male students. These findings are in accordance with the study conducted by Murphy and Begss [2] that stated that female students were more enjoy science and more appreciative of the impact of science on their lives outside school [2]. Johnston, et al. have also reported that female students enjoyed studying science class more than male students did [10]. 
Table 5 Significance value of the t-test.

\begin{tabular}{|c|c|c|c|c|c|c|c|c|}
\hline & & \multicolumn{7}{|c|}{ t-test for Equality of Means } \\
\hline & & \multirow[t]{2}{*}{$\mathrm{t}$} & \multirow{2}{*}{ Df } & \multirow{2}{*}{ Sig. (2-tailed) } & \multirow{2}{*}{$\begin{array}{c}\text { Mean } \\
\text { Difference }\end{array}$} & \multirow{2}{*}{$\begin{array}{l}\text { Std. Error } \\
\text { Difference }\end{array}$} & \multicolumn{2}{|c|}{$\begin{array}{l}95 \% \text { Confidence } \\
\text { Interval of the } \\
\text { Difference }\end{array}$} \\
\hline & & & & & & & Lower & Upper \\
\hline \multirow[t]{2}{*}{ Attention } & Equal variances assumed & -1.689 & 116 & .094 & -.15942 & .09438 & -.34636 & .02752 \\
\hline & $\begin{array}{l}\text { Equal variances not } \\
\text { assumed }\end{array}$ & -1.697 & 115.445 & .092 & -.15942 & .09394 & -.34549 & .02665 \\
\hline \multirow[t]{2}{*}{ Response } & Equal variances assumed & -2.131 & 116 & .035 & -.20936 & .09825 & -.40395 & -.01477 \\
\hline & $\begin{array}{l}\text { Equal variances not } \\
\text { assumed }\end{array}$ & -2.134 & 115.913 & .035 & -.20936 & .09811 & -.40368 & -.01504 \\
\hline \multirow[t]{2}{*}{ Motivation } & Equal variances assumed & -.520 & 116 & .604 & -.04802 & .09242 & -.23107 & .13502 \\
\hline & $\begin{array}{l}\text { Equal variances not } \\
\text { assumed }\end{array}$ & -.516 & 108.781 & 607 & -.04802 & .09302 & -.23240 & .13635 \\
\hline
\end{tabular}

\section{Conclusion}

The degree of attitude towards science observed from students of the SMK Bakti Nusantara 666, Bandung, Indonesia after given a lecture on introduction to nanotechnology was quite good. This finding was represented by the scores of four indicators as follows: interest at $69.05 \%$, attention at $69.22 \%$, response at $69.89 \%$ and motivation at $71.04 \%$, relative to the expected score. The average score of attitude towards science for female students reached $71.45 \%$ of the expected score. The scores for indicators which are interest, attention, response and motivation were $71.2 \%, 70.9 \%, 72.1 \%$ and $71.6 \%$, respectively. The scores were lower for male students, where the corresponding scores for interest, attention, response and motivation were only $67.0 \%, 67.7 \%, 67.8 \%$ and $70.6 \%$, respectively. This resulted in average score for attitude toward science as much as $68.3 \%$ relative to the expected score. No significant differences in attention and motivation between female and male studets were observed. However, the response rate and motivation was significantly higher in female students compared to all students.

\section{Acknowledgement}

This work was financially supported by the Community Services Grant, Institut Teknologi Bandung in the fiscal year 2014 and DIPA-RM 2014 UIN Sunan Gunung Djati Bandung.

\section{References}

[1] Depdiknas, "Kurikulum mata pelajaran Ilmu Pengetahuan Alam untuk Sekolah Menengah Pertama (SMP)/Madrasah Tsanawiyah (MTs)", 2006

[2] C. Murphy and J. Beggs, "Children's perception of school science", SSR, 84(308), pp. 109 - 116, 2003.

[3] R. Alfiah, "Upaya peningkatan keterampilan berpikir kritis siswa dengan menggunakan model pembelajaran kooperatif tipe investigasi kelompok (group investigation) pada materi pokok alat optik (Penelitian Quasi Experiment terhadap Kelas X MAN Pacet)", unpublished.

[4] A.Smithers and P. Robinson, "The growth of mixed A-levels", Department of Education, University of Manchester, 1988.

[5] J. Osborne, "Attitudes towards science: a review of the literature and its implications", Int. J. Sci. Educ., 25 (9), pp. 1049-1079, 2003.
[6] L. E. Klopfer, "A Structure for the affective domain in relation to science education", Sci. Educ., vol. 60(3), pp. 299-312, 1976.

[7] P. L. Gardner, "Attitudes to science: a review", Stud. Sci. Educ. 2(1), pp. 1-41, 1975.

[8] OECD, Assessing scientific, reading and mathematical literacy: a framework for PISA, OECD, Paris, 2006.

[9] W. J. Popham, K. A. Sirotnik, "Educational statistics: use and interpretation", Harper \& Row, Inc. 1973.

[10] J. Johnston, E. McKeown, P. Cowan, B. McClune, A. McEwen, "What science engenders: boys, girls and the teaching and learning of primary science", Belfast: Equal Opportunities Commission for Northern Ireland, 1999. 